loop at the end of the helix. On the basis of comparison of existing structures, it may be very difficult, if not impossible, to differentiate between insertions that occurred in loops, as opposed to insertions that originally occurred in helices but were propagated into neighbouring loops.

Received 13 July: accepted 30 November 1992.

1. Pascarella, S. \& Argos, P. J. molec. Biol. 224, 461-471 (1992)

2. Barany, F. Proc. natn. Acad. Sci. U.S.A. 82, 4202-4206 (1985)

3. Sondek, J. \& Shortle, D. Proteins: Struct. Funct. Genet. 7, 299-305 (1990)

4. Sondek, J. \& Shortie, D. Proteins: Struct. Funct. Genet. 13, 132-140 (1992).

5. Freimuth, P. I., Taylor, J. W. \& Kaiser, E. T. J. biol. Chem. 265, 896-901 (1990)

6. Marti, T., Otto, H., Rösselet, S. J., Heyn, M. P. \& Khorana, H. G. Proc. natn. Acad. Sci. U.S.A. 89 1219-1223 (1992).

7. Starzyk, R. M. Burbaum, J J. \& Schimmel, P. Biochemistry 28, 8479-8484 (1989)

8. Ladant, D., Glaser, P. \& Ullmann, A. J. biol. Chem. 267, 2244-2250 (1992)

9. Heinz, D. W., Baase. W. A. \& Matthews. B. W. Proc. natn. Acad. Sci. U.S. A. 89, $3751-3755$ (1992)

10. Eriksson, A. E. et at. Science 255, 178-183 (1992)

11. Gray, T. M. \& Matthews, B. W. J. molec. Biol. 175, 75-81 (1984)

12. Milner-White, E. J. \& Poet. R. Trends biochem. Sci. 12, 189-192 (1987).

13. Mcintosh, L. P., Wand, A. J., Lowry, D. F., Redfield, A. G. \& Dahlquist, F. W. Biochemistry 29, 6341-6362 (1990).

14. Lee, B. \& Richards. F. M. J molec. Biol. 55, 379-400 (1971)

15. Connolly, M. Science 221, 709-713 (1983).

16. Lesk, A. M. \& Chothia, C. J. molec. Biol. 136, 225-270 (1980)

17. Presta. L. G. \& Rose, G. D. Science 240,1632-1641 (1988).

18. Bashford, D., Chothia, C. \& Lesk, A. M. J. molec. Biol. 196, 199-216 (1987)

19. Dao-pin, S., Baase, W. A. \& Matthews, B.W. Proteins: Struct. Funct Genet. 7, 198-204 (1990)

20. Zhang, X.-J., Baase, W. A. \& Matthews, B. W. Biochemistry 30, 2012-2017 (1991).

21. Becktel, W. J. \& Scheliman, J. A. Biopolymers 26, 1859-1877 (1987)

22. Matsumura, M. \& Matthews, B. W. Science 243, $792-794$ (1989).

23. Kunkel, T. A., Roberts, J. D. \& Zakour, R. A. Meth. Enzym. 154, 367-382 (1987)

24. Poteete, A. R., Dao-pin, S., Nicholson, H. \& Matthews, B. W. Biochemistry 30, 1425-1432 (1991)

25. Streisinger, G., Mukai, F., Dreyer, W. J., Miller, B. \& Horiuchi, S. Cold Spring Harb. Symp. quan Biol. XXVI, 25-30 (1961).

26. Weaver, L. H. \& Matthews, B. W. J. molec. Biol. 193, 189-199 (1987)

27. Jancarik, J. \& Kim, S. H. J appl Crystallogr 24, 409-411 (1991).

28. Alber, T., Dao-pin, S. Nye, J. A. Muchmore, D. C. \& Matthews, B. W. Biochemistry 26, 3754-3758 (1987).

ACKNOWLEDGEMENTS. We thank S. Pepiot, J. Lindstrom and B. Simon for technical assistance an X.-J. Zhang, R. DuBose, E. P. Baldwin and M. Blaber for discussion. D.W.H. acknowledges the support of the Deutsche Forschungsgemeinschaft. This work was also supported in part by grants from the NIH (to B.W.M.), NSF (to F.W.D.) and the Lucille P. Markey Charitable Trust.

\section{GUIDE TO AUTHORS}

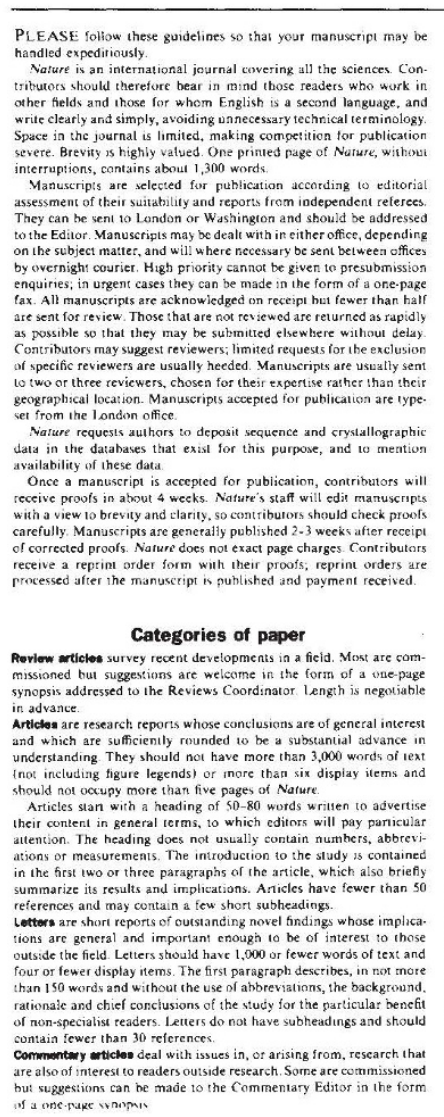

\section{ERRATUM}

\section{Evolution and environment in the Hominoidea \\ Peter Andrews}

Nature 360, 641-646 (1992)

IN this Review Article, in the figure in Box 4 on page 644, the labels 'Orang' and 'Human' in the diagram labelled "Classification at family, subfamily and tribe level of the Hominoidea" were inadvertently transposed.

\section{CORRECTIONS}

\section{Molecular and genetic damage in humans from environmental pollution in Poland}

Frederica P. Perera, Kari Hemminki, Ewa Gryzbowska, Grazyna Motykiewicz, Jadwiga Michalska, Regina M. Santella, Tie-Lan Young, Christopher Dickey, Paul Brandt-Rauf, Immaculata DeVivo, William Blaner, Wei-Yann Tsai \& Mieczyslaw Chorazy

Nature 360, 256-258 (1992)

IN Table 1 on page 257, the $P$ values for the comparisons of PAH-DNA adducts between the 'Exposed winter' (EW) to 'Control summer' (CS) and 'Exposed summer' (ES) to CS are reversed. The correct $P$ value for the comparison of EW to CS is 0.012 and that for the comparison of ES to CS is 0.078 , as expected from the means in the table. The correct $P$ values further strengthen the finding of an effect of air pollution on DNA adducts.

\section{Cloning and characterization of a gene that regulates cell adhesion}

\section{W. E. Pullman \& W. F. Bodmer}

Nature 356, 529-532 (1992)

SHOWN below is a revision of the nucleotide sequence and inferred amino acid sequence for a cellular adhesion regulatory molecule, the gene for which is now known as CMAR (CAR in this letter). The authors acknowledge helpful information received from Drs Alejandro Aruffo and Po-Ying Chan of Bristol-Myers Squibb, Pharmaceutical Research Institute, Seattle, USA, and H. Durbin (ICRF) in making this correction.

\section{CMAR \\ GCATGGAACACTTCGAGTTCCCAGGGTTATAGACAGTCGTTCCCAGTGTGG CTGAGGCCACCCAGAGGCAGCAGAGCATTCAGACTCCAAACAGACCCCTGT TCATGCCGACGCTTGCACGACCGCCCCAGTTCCTGTGGCTCCCTCGGAATG - M - \\ CTAAGGGGATCGGACATGAAAGGACCCTGTGAGCCGATTGTCCTATCTCCA $\begin{array}{lllllllllllllllll}L & R & G & S & D & M & K & G & P & C & E & P & I & V & L & S & P\end{array}$ \\ GCGGCCCTGTCATCCAGCTCACTCATCAATGGGGCCAGTCAGGCCCAGGCA

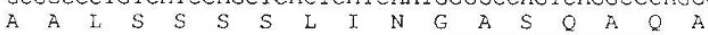 \\ CTGGGCTCCGGAGGACTCACCACTGCCCCCTGCTGCCATGTGGACTEGTGC G S G G L T T A P C C H V D W C AAGTTGAGGACTTCTTGCTGGTCTAGTCACGCATGCAGTGTTGGGGATGCC $\mathrm{K} T \mathrm{R}$ T S C W TTEGTTTTTACTGCTCTGAGAATGTTGAGATACTTTACTAATAAACTGTG \begin{tabular}{lllllllllllll}
$L$ & $V$ & $F$ & $T$ & $A$ & $L$ & $R$ & $I$ & $V$ & $E$ & $I$ & $I$ & $Y$ \\
\hline
\end{tabular}

